\title{
The Building of Consent: Initiation Rituals and Students' Power Relations in the University of Coimbra
}

\author{
Elísio Estanque ${ }^{1,2}$ \\ ${ }^{1}$ Centre for Social Studies (CES), Portugal \\ ${ }^{2}$ Faculty of Economics, University of Coimbra, Portugal
}

Copyright $\bigcirc 2017$ by authors, all rights reserved. Authors agree that this article remains permanently open access under the terms of the Creative Commons Attribution License 4.0 International License

\begin{abstract}
This article ${ }^{1}$ covers three areas. The first (i) gives a brief historical overview of the University of Coimbra and outlines some of the academic traditions, as well as violent behaviour associated with the initiation rituals (known as Praxe). The second area (ii) explores the possible links between these rituals and various cultural and socio-political movements, especially during the authoritarian regime. Finally (iii), the study analyses the most recent trends of the phenomenon in Portugal. The research purpose is to reveal the massive dimension of this phenomenon and its specificities in the case of Coimbra, the hometown of the Portuguese university where all these rituals started, about 700 years ago. The article is based upon a qualitative and reflexive methodology, and the empirical data has been gathered, firstly, from historical documentation and secondly, by permanent and direct observation over more than 30 years of living and dealing (as a professor) with the daily life of students in this city. This became a public issue after a number of controversial incidents, with trends very often shifting towards abuse, humiliation and violence. The culture of submission in the face of power that most initiation rituals foster seems to express a dormant tendency in society, where consumerist individualism is combined in a perverse way with mechanisms of avoidance and unconditional surrender to disciplinary rationales of a despotic nature.
\end{abstract}

Keywords Initiation Rituals, Academic Tradition, Student Movement, University of Coimbra

\footnotetext{
${ }^{1}$ This paper is produced under the research project "Rebuilding trade union, power under austerity age: three sectors under review" (PTDC/IVC-SOC/3533/2014 - POCI-01-0145-FEDER-016808), taking place at the Center for Social Studies, University of Coimbra, between June 2016 and May 2018.
}

\section{Introduction}

This essay aims to underline the historical heritage of the traditions handed down to the university students and to introduce a reflexive perspective that analyses these phenomena as part of the process of legitimization and reproduction of power relations and mechanisms of consent among students. The academic initiation rituals - here called Praxe - were the pretext for trying to learn more about the current young student world from the context, and history of the University of Coimbra (hereinafter referred to as UC).

This is one of the oldest institutions of higher education in the world, in which tradition and students' rituals were born centuries ago. But today, considering all the deep transformations of society and university, these traditions have suffered a sociological shift in that they have been contaminated by the new trends of consumerism and alienation on the part of the students. The cultural scene was quite different when the University was exclusively the world of the elite's offspring. So, the other side of the democratic access (of the middle class and working classes children) to public universities favoured the current trend towards mass behaviour exhibited by the student youth. This is the context in which we need to look at the subversion process of traditional rituals and how that process helps rebuilding collective identities, giving rise to new forms of symbolic power in which consent and despotism are accepted and largely naturalized by students.

The so-called Praxe, or initiation rituals, refers to a variety of behaviours and rituals that can be taken in a broader or narrower sense. The Código da Praxe [Initiation Rituals Code] that is in force in the University of Coimbra (with 290 articles) ${ }^{\mathrm{i}}$ defines Praxe simply as 'the set of customs and practices traditionally existing among the students'. In line with the idea of 'initiation ritual' suggested by the anthropologist Van Gennep [1], initiation rituals can be defined as the symbolic survival of rites-of-passage, presentification and hetero-recognition, marked by gestures that try to mark the debrutalisation of learning and idolization of the intellectual craft, starting from the principle 
- enshrined in the very nomenclature (the donkey, the goat, the rattle, the magna besta, etc.) - that the human being is born a beast' (in Relatório da Assembleia da República, 2008 [Report of the Assembly of the Republic]). ${ }^{\text {ii }}$ Such rituals, sometimes regarded as integration mechanisms, aim to 'test' or 'try out' the 'novice', the 'recruit', the one who has just achieved a new state or arrived in a new community and must submit to it.

Unlike in other countries, these practices are, even today, a genuine mass phenomenon in Portuguese universities. According to a recent international study, ${ }^{\text {iii }}$ about $73 \%$ of young Portuguese university students reported having undergone some serious initiation rituals when they entered the University (while the average for the countries studied was $25 \%$ ); $59 \%$ of Portuguese students stated that such acts had 'psychological consequences' on their life, and 20\% said that they had led them to drop out.

Considering the sociological impact on the Portuguese student youth, and at the same time their deep historical roots, especially in the UC, this article surveys the historical roots of academic traditions in the country. It therefore provides a brief ethnographic record setting out some of the forms of the initiation rituals and the heritage richness of what is known in Portugal as "The students' city». It tackles aspects such as: the violence traditionally associated with these practices; the tensions and conflict that, over the centuries, have been a feature of the relations between the student elite and the local community; the possible connection between the initiation rituals and the multiple sociocultural and political movements that characterized successive generations; the question of the subordination of the role of women and its relationship with the marialva and the sexist culture, in a once exclusively male university; and, finally, the most recent trends of the initiation rituals phenomenon in this country, where some incidents, and even tragedies, like that of Praia do Meco (15/12/2013) in which six young students drowned while undergoing an initiation ritual, with trends very often edging towards abuse and violence. These are some of the areas that this article seeks to explore and discuss. The humiliation and submission in the face of power that most initiation rituals entail seem to express a dormant tendency in society where consumerist individualism is combined in a perverse way with rationales of avoidance and unconditional - and apparently voluntary - surrender to the power of the stronger.

\section{Literature Review}

Any attempt at a sociological interpretation of the initiation rituals must bear their historical significance in mind, but it is especially important to focus our attention on the meaning(s) they have acquired today. That is the main reason why it makes sense to start from the present and direct the discussion to the past, that is to say, towards a reinterpretation of history based on current narratives that frequently tend to the mystification and naturalisation of 'tradition'. Of course we must assume that "naturalism" is a process of a subjective discourse in which harmony and social control is out of question. Moreover, as suggested by M. Burawoy [2], ideology plays a decisive role in presenting this as natural and inevitable at the eyes of a community in the making - the students' community - who is always searching for new elements of identity rebuilding. On the other side, following P. Bourdieu [3], we shall bear in mind that this is a logic from bellow, but it is not apart from the top down hierarchical academic system, struggling for its own perpetuation as a disciplinary order and legitimated form of institutional power.

Although this paper mainly focus on university traditions, we should not forget that historically these practices are not exclusive to higher education. The old boarding schools and other closed and disciplinary institutions like houses of correction, for the education and reintegration of celibate youth communities - overwhelmingly male institutions promoted and recreated their rules of conduct by subjecting the youngest and newest arrivals to the authority of the older members. In short, for a long time symbolic and physical violence in various forms, such as the use of a ruler, a wooden spoon or a pointer, were regarded as a necessary ingredient of education. Following Foucault [3] and also Elias [4], under authoritarian regimes, in particular, the role of the educational institution was no stranger to violence, and even legitimized it as a condition for cultivating civility, discipline and a respect for the values and customs protected by the authority.

The discourse that appeals to the past, although centred on tradition, is always a reflection of the present and, therefore, a process of reinvention of tradition. This is true of student subjectivities justifying the perpetuation of these rites-of-passage. Invoking tradition to promote today's recreational and ritualistic activities is actually a piece of fictional representation. The common sense discourse appealing to the past is always a reinvention of that past. Thus, any attempt at a sociological interpretation of these phenomena must bear in mind their historic significance, but above all it must focus attention on the meaning(s) they have been acquiring in the present. Most recent theoretical tendencies build up an image in which young people are taken as vehicles of increasing individualism, consumerism and vulnerability.

As a legacy of the Welfare State and consumer society, not forgetting that in Portugal this social model only expanded from the 1980s onwards, such reference has not been vanquished and is still influential, especially among middle class families (these being most closely related to the academic world). So, we can say that the hedonistic immediacy or deliberated alienation noted by Lipovetsky [5] in The Era of Emptiness, continued to impact on youth sociability in Portugal:

'the disturbing increase of anxiety, of depression, of several behavioural psychopathological disorders. (...) 
The dominant feature of democratic individualism was, for a while, the euphoria of liberation; now, more than ever, it is the fear of living, the insecurity, the fear not only linked to terrorism, but to anything: food/nutrition, relationships, age, work, retirement.' (p. 21)

Of course, in the context of the recent crisis, the increasing commodification of the economy, labour and society created a rising elusiveness of and barrier to opportunities that pushed youth towards new forms of engagement in protests, in particular in the 2011-2012 cycle as Estanque and Fonseca [6] underline. However, that was no more than a momentum that has not erased the overall relative indifference of the younger generation to politics and active citizenship, as noted by Estanque and Bebiano [8]. However, the current confusion has not erased many of the signs that for decades have been indicating the consumer society. Many authors such like Marcuse [9], Debord [10] and Baudrillard [11] stressed that such signs include widespread cultural dissemination through the media, the instrumentalisation of academic credentials, and the weakening of emancipatory social movements. In Portugal, citizenship shortfalls are deep and old. They last for centuries and the crisis of the last decade only fuelled those old pathologies, fears and a certain propensity to 'self-flagellation', as stated by Gil [12] and Santos [13]. Looking at that process from the social upheaval that has occurred in the country, especially since the democratic liberalization of 1974, there is no doubt whatsoever as to its far-reaching impact on the academic field and its diverse forms of sociability, as I emphasised before [14] and [21].

That said, it is also important to retrieve some of the communitarian legacy build up in the students residences (known as Republics) and the role they have played, especially in Coimbra in the 1960s. For a deep understanding of these trends among youth in the recent decades we also need to revisit the legacy of collective struggles and forms of resistance during the Salazar's dictatorship. It seems that the current forms of sociability and subjectivities have broken the connection to those struggles. It should be remembered that the communitarian atmosphere of the Republics was prominent in this respect, by stimulating irreverence, solidarity and a critical spirit among the students. As I've been stressing in other text [20], this was the extent to which they asserted themselves as crucial foci of various movements and forms of dissidence relative to the conventional standards and the Salazar-Caetano regime. However, the Repúblic's environment also changed significantly from the mid-twentieth century. At the beginning of this cycle, in the charter of the Council of Republics (1948) was stated that they were 'united by the praxe', but that position evolved into a more culturalist and interventionist conception in the early 1960s. Like stated by Cardina [15].

'Instead of focusing on their more bohemian and playful side, the Republics now define themselves as «centres for the students' cultural education, groups governed by the democratic principle of self-management, enjoying economic and ideological independence, free from any kind of authority»' ( $p$. 125)

Also Cruzeiro [16] and Namorado [17] share this analytical perspective. Despite the closure of the country, the echoes of international social movements in the sixties, particularly in May 1968, could not help but infect some sectors of Portuguese student youth. From the late 1950s, the left-wing opposition tendencies were committing to a solidaristic conception of the initiation rituals. They were seeking to influence the traditionalist media to instil a new concept of 'politics' while at the same time trying to imprint a demanding and militant direction on the associative movement. Following Cardina [18], this was expressed in the language of the epoch as a 'trade unionist' perspective of the student movement. At that time, these different arenas of student culture were practically inextricable. The conservatism of the Salazarist University, backed up by the narrative of Catholic morality - the official doctrine of the regime and its anti-communism, anti-democracy - helped to lift the first students movements. However, in the late sixties, in contrast, students' attitudes started to turn to more cultural aspects in the fraternal and solidarity sense. This attitude tended to spread among the university youth through music, poetry and the collectivist spirit that flourished in the students residences (especially the Republics), thereby instilling a degree of political direction that came to be expressed in the irreverence, imagination and creativity of a generation that was gaining political awareness. Such awareness led to the rejection of the old scholastic approach to teaching and encouraged aspirations to freedom and especially with the start of 1960s and the war in Angola - fear of conscription into the armed forces ${ }^{\text {iv }}$.

It is customary to think that the most powerful periods of mass mobilization - that is, when gesellschaft (society) gains strength and gemeinschaft (community) recedes - stimulate change but they can also contribute to greater social cohesion. Although in a different register, many social scientists cite Émile Durkheim, who in the nineteenth century showed how the loss of social bonds and the blurring of common beliefs lead to pathologies, especially when individuals submit unreservedly to the coercive force of the social, relinquishing their active involvement in the revitalization of society's moral beliefs and values. During the long dictatorship in Portugal (1926-1974), state control and repression regulated national society in a conservative manner, and that order could sometimes induce a sense of community through resistance, as exemplified by youth rebellion and student struggles in Coimbra and Lisbon during the sixties. Nevertheless, of course, society today is far more complex. As Ulrich Beck puts it [19], global risk societies are caused by the growing strength of markets. According to Castells [20], we live today in an era of networks of outrage and hope, but the sense of 'future' has been largely erased from youth subjectivities. For that reason, social science not only needs 
to search for and map signs of hope and despair among youth but also to understand the sociocultural factors that inhibit outrage and collective movements. The sense of rebellion and emancipation has become weak among students, even in contexts such as that of Coimbra, where students movements have been part of the community culture, as I have argued in recent papers such as [14] and [21].

\section{Research Process and Methodology}

The focus of this study evokes an 'archaeological methodology', trying to rebuild the past through the present, that is, following Foucault's approach [2], trying to shed light on that past in an effort to clarify certain traits that this phenomenon has latterly been revealing. So, the sample case - the University of Coimbra - was chosen for obvious reasons: first, because it was the only university in the country from 1290 to 1911 (the year the universities of Lisbon and Porto were founded); second, because this is the original site of students and academic roots and traditions in Portugal; third, because, even today, all other higher education institutions (where these rituals take place) see Coimbra as the original reference and invoke its 'authenticity'; and finally, because this is the sociological terrain where I have been observing students rituals and daily life for the last thirty years.

In what concerns methodology and research process, my option is inspired by reflexive analysis and by my own autobiographical experience. Moreover, the approach combines 'participant observation' with the 'extended case method', drawing on sociologists like B. Santos [22], M. Burawoy [23] and G. Alan-Fine [24]. It aims to avoid determinism and relativism, putting forward an interactive and multi-causal framework through which one can look at the phenomena from below while paying attention to the external forces that shape them. It is not a question of searching the micro-foundations of the macro-structure or the macro-foundations of the micro-structure but instead of taking the two dimensions as interacting in order to allow the empirical reality to reformulate previous hypotheses and theories about the broader social context.

The UC is, by definition, a nostalgic place. This reflects on the local culture, on the fado of Coimbra (romantic ballads sung by students), poetry, on legends such as the one of Pedro and Inês $\mathrm{v}$. It was the place of a cultural and aesthetic resistance throughout the fascist regime, and above all, it has been the birthplace of modern youth. In fact, over the centuries the university has been the main terrain where dissent, bohemian and subversive forms of life styles could flourish. In a male-dominated world, as in any closed institution of the same kind, violence, virility and symbolic rituals became part and parcel of such collective identities. Clearly, the issue of gender relations is particularly felt in environments where socialisation between the two sexes is constrained for one reason or another. Barracks, boarding schools and seminaries, for example, are institutions where gender segregation is generally established in the internal regulations. These, then, are some of the reasons why this case is relevant. Another important point is that this relevance is justified by what its legacy says about a deeper understanding of today's academic youth.

As a starting hypothesis, I assume that the strong presence of a narrative invoking the 'authenticity of tradition' to justify the apologetic approval of Praxe is the main reason for legitimating despotic power and consumerist cultures of the present among students. Together, these two core points (tradition and consumption) contain the elements that increase consent and reproduce power relations among older ('doutores') and freshmen students ('caloiros'). There is a sort of disciplinary order stimulating old hierarchies on the grounds of antiquity, which spreads out from this academic environment but appeals to a holistic scheme. The underlying message seems to be the following: 'look, the experience of submission here is a good education for the rest of your lives; it helps you to find a good job in the future'. Above all, naturalising power relations using different forms of tests, symbolic violence through different sorts of games and rituals, is a way of erasing democratic culture and expelling the critical spirit from the students body.

Technical procedures used different sorts of information. (i) Gathering and analysing historical documents, books and reports about Coimbra in the past. (ii) Content analysis of the so called Código da Praxe (the official document that prescribes student behaviour in students' rituals. It has 290 articles). (iii) Interviews with former students, leaders of the students association, members of the Veterans Council (who regulate the Praxe rituals), former and current leaders of the Academic Association (AAC). (iv) Video reports on the situation in other universities in Portugal. (v) Results of surveys produced under previous projects (see [8]) as the one mentioned bellow; (vi) Finally, I have gathered many observations in the course of more than ten years following these rituals, which took place in public areas, especially in certain periods of the academic year. Another important source was an international study conducted by the platforms Universia and Trabalhando.com ${ }^{v i}$. The findings showed that 73 per cent of Portuguese students admitted having suffered some kind of Praxe (designated in that study as 'heavy jokes') when they got to the university, while the average for hundreds of Latin America universities (and some European) was 25 per cent. Furthermore, 59 per cent of Portuguese students stated that those acts had had a psychological impact on their lives and 20 per cent said that the experiences influenced the interruption of their academic studies.

Using this methodology, I discuss the mentioned dimensions, putting together the past and the present. The discussion is structured as follows: (i) traditional rituals and the violence they involve are related to the particular status of the university body ${ }^{\text {vii }}$; (ii) social divisions between rich and poor, university and local community and the emerging 
bohemian culture among students; (iii) the period of resistance against Salazar's regime when rituals became combined with rebellious behaviour; and (iv) the more recent trends that exhibit new forms of abusive power relations among students.

\section{Research Field/Discussion}

\subsection{Rituals and Violence along History: Assaults, Kicks, Teasing and Troupes}

Shortly after its founding in $1290^{\text {viii }}$, the Portuguese University (Universidade Portuguesa) was installed in Coimbra for the first time in 1308. A year later, the king, D. Dinis, issued a decree setting out hours of study and curfew for students, establishing that offenders should be monitored and punished by senior students (according to their hierarchy, based solely on the seniority of each member). Underlying these early regulations was the exclusivist status enjoyed by the restricted elite which, in this first stage, benefited from royal protection. It was at this time (1308) that D. Dinis issued his Charta Magna Privilegiorum (updated version of the 1290 founding charter of the University), which established a series of measures intended to discipline and also to protect the students. It clarifies some of his concerns about the exclusiveness of the student status and establishes measures designed to safeguard the defence of its special prerogatives. Shortly after the definitive transfer of the University to Coimbra in 1537 , royal provisions were established by D. João III, aiming at limiting and prohibiting the carrying of weapons, a threatening resource then commonly used in situations of conflict between students and between them and other popular groups.

From the early $18^{\text {th }}$ century we find the Investidas (assaults), that is, violent acts perpetrated by groups of older students (generally wearing hoods), that included mocking the freshmen and inflicting punishment on them. Some of these acts were related to the scarcity of means of transport of the mediaeval era, when journeys to Coimbra were extremely slow and often rough. Students would often arrive on donkeys, mares and mules. Horses and stagecoaches were strictly for the few from the upper echelons of noble and aristocratic families. Eduarda Cruzeiro [25] refers to the freshmen students who in this context have become:

'victims of muleteers and innkeepers, voracious exploiters who do not spare their bags or their bodies, usurping the first from the mounts half-way, stripping from the second the comforts of bed and table that they should be afforded' (p. 810).

This was the picture that many of the newcomers (freshmen) encountered for the first time with their older colleagues. It is in the investidas that this mixture of practices is more apparent, in the ritualized and humiliating reception of the freshman and the hustling actions, close to criminality. The renowned Rancho de Carqueja was one of the most violent groups of the time (1720-1721). According to Bastos [26], such were the outrages, including the kidnapping of maidens, ${ }^{i x}$ that the king, D. João V:

'sent them as convicts to India, and their leader, Francisco Jorge Alves, from Vila da Feira, having been accused of murder, was beheaded [in the pillory, on 20 June 1722]. His head was sent to Coimbra and exhibited here in the Praça de S. Bartolomeu (since 1 July 1722)' (p. 816).

And another important figure that passed through Coimbra University at that period stated that these acts were banned by decree of D. João V (in 1727) - as mentioned by E. Cruzeiro $[25]^{\mathrm{x}}-$ in his criticism of the student customs of the epoch:

'there was no defence for those barbarous and indecent assaults, committed with violence by defiant, armed attackers as though attacking a castle: and these excesses resulted in deaths, fires and sacrileges'... The process was led by the Reforming Rector (D. Francisco de Lemos), who nevertheless complained two years later about 'some change in peace and order caused by some vagrants who dressed in cassocks to pass for students and were getting into the students' houses and disturbing them' (p. 817).

Crime and chaos remained very serious problems throughout the second half of the eighteenth century and this led the government of the Marquis de Pombal to undertake a thorough reform of the working of the University (in 1772). This reform not only focused on the processes and content of the courses taught, it also addressed the area of discipline, including the criteria for admitting students. Following Torgal and Dias [27], in any case, as a result of the reform the number of UC students was substantially reduced, going from about 3000 to about 800 in a few years after the reform.

The referred Investidas included the persecution and subjection of the freshmen, and the infliction of physical violence on them. They could take the form of 'trials' and the activities of the Trupes [literal translation, 'troupes'] (acts which still exist under the current initiation rituals, or praxe), such as public humiliation, caning to the point of drawing blood, shaving the head and beating the fingernails ${ }^{\mathrm{xi}}$. In 1864 , when the railway line connecting Lisbon-Coimbra-Porto was inaugurated, Largo da Portagem was a favourite place for accosting the novices with the first assaults, mockery and rituals, mainly in the month of October, but they were repeated throughout the academic year. The scenario included a whole menu of initiatives and a very particular terminology. At least until the middle of the twentieth century, the world of Coimbra's academic traditions had created and reproduced a cosmology and lifestyle of its own, which, as has been said by Nunes [28], only had the reach it did inasmuch as it was the creation of a restricted and powerful elite.

The Academic Forum, also known as Judgement of the 
Conservatory of the UC (created by king D. João I in 1408) guaranteed the members of the university corpus a status of exemption that kept them safe from the demands of civil justice (including the Academic Prison, established in 1593 and extinguished in 1834). ${ }^{\text {xii }}$ It is linked to the generalized use of academic garb, ${ }^{\text {xiii }}$ intended to set the university body apart from the rest of civil society. The Academic Police force was formed in 1836 in the wake of corporate pressures that demanded the preservation of university autonomy. In the mid-nineteenth century, the patrolling of the town was split into three patrols, with the halberdiers instructed to force the students to go back home after the evening tolling of the 'Cabra' ${ }^{\text {xiv }}$ According to Lamy [29] there were six soldiers on each shift and one or two halberdiers. How this force behaved in relation to the student community and the people of Coimbra would, however, be the subject of controversy and challenge and it was finally abolished in the period of the First Republic.

The same mentioned source also refers that the powers and privileges of the Academic Police were curbed as of 1883, which helped to intensify the activities of the Trupes. These consist of groups of at least three students, led by a chief, formally intended to enforce the rules of the initiations rituals, conduct a Trial (of a freshman) or comply with a directive of the Council of Veterans. ${ }^{\mathrm{xv}}$ They remain to this day, even though they are almost shrouded in controversy and contentious issues for broad social and student segments (they operate wearing the academic garb and no colours are visible other than black). The leader of the trupe is the oldest in the group hierarchy, ${ }^{\text {xvi }}$ and is always accompanied by the essential symbols of the initiation rituals - scissors, wooden spoon and club. In former times the trupes were the main factor controlling and exercising violence on the novices/freshmen. If he was caught outside the house after the evening tolling of the Cabra [one of the bells in the university tower] (18.00-18.30), the 'fugitive' freshman (caught on the street out of hours) ${ }^{\text {xvii }}$ could be hunted by these groups of older students armed with clubs, shears, canes, pistols. In such cases, he could be a victim of a partial or complete haircut - known as 'tonsure' or 'shearing' - and caning of the hands or fingernails, but he could even have to defend himself in a 'duel' with the leader of the trupe; if he won there would be no sanctions as suggested by Frias [30]. Cases illustrating how these actions were a sometimes dangerous mixture of corrosive irony and psychological pressure, but as a rule involving physical violence, were repeated over the centuries. According to Lamy [29], one consulted source reports that one night in December 1841:

'a security corps patrol shot José Costa Lobos, a terrible 3rd year student thug, from behind', and that 'in 1858, several trupe members were guests of the academic prison for eight days, among them were the well-known Antero de Quental and Alberto Sampaio' (p. 694).

The term Praxe [initiation rituals; rites-of-passage] began to be used from the second half of the nineteenth century.
Indeed, as stated by Nunes [28], some sources cite the year 1863 as the date of the first known reference to this ritual, which was at the time associated with the adjective 'savage', that is, with a term that evokes the cruel and violent nature already ascribed to these acts. Before that, written references to student rituals before 1850 are thin given the dominance of oral transmission whereby the processes were passed on to the younger students by the veterans, by former students to their children, over successive generations. In any case, from the mid-eighteenth century the main reference to student rituals and traditions was the classic publication Palito Métrico. ${ }^{\text {xviii }}$

\subsection{Rich, Poor and Bohemians}

In Coimbra, the persistent contradiction that came to define the relationship between the students and the rest of the city's population (the so-called 'commoners' ${ }^{\text {xix }}$ ) is very evident. From the mid-nineteenth century, when academic associativism (also seen among nineteenth craftsmen and workers) was starting to gain strength, various institutions began to appear in the city, such as the Academia Dramática de Coimbra [Coimbra Drama Academy] (1852), which merged with the Clube Académico [Academic Club] (1861) leading to the birth (in 1887) of the Associação Académica de Coimbra [Academic Association of Coimbra] (hereinafter, AAC). The Sociedade de Instrução dos Operários [Workers' Education Society](1851) came earlier, but to counterbalance the benevolent initiatives of the students, a body known as the Academic League (Liga Académica) was formed, according to C. Cruzeiro, a well-known activist in 69's protests [16], to:

'support the removal of all relationships of students with the offspring of the land by making a nocturnal patrol of the city to protect the students and organise a consumer cooperative whereby, on behalf of the members, they sent foodstuffs from outside Coimbra' ( $p$. 831).

In the early twentieth century, especially during the First Republic (1910-1926), alongside the excesses of ritualism and violence, the politicization of the students spread rapidly and with it came protest actions, in particular to claim the rights and conditions for the full exercise of civil liberties. Such a trend could not fail to contaminate the students, especially in this particularly troubled period of the Portuguese society. The so-called Taking of the Bastille, which occurred on the night of November 24 to November 25,1920 , was one of the culminating moments of this atmosphere. It involved a group of students who invaded and occupied the Clube dos Lentes (a luxurious lounge for lecturers to relax in); a truly 'revolutionary' action, demanding suitable premises for the headquarters of the AAC, which had not existed until then.

Nonetheless, the atmosphere of city's daily life, although undoubtedly subjected to the changing times, did remain for 
centuries as a context where, even though the student body was extremely elitist, the poverty and degradation of the buildings, the student housing and the general urban landscape were striking features of the city. Although we know that the social origins of the student body were predominantly from the upper classes, namely the noblemen, the nobility of the robe, the sons of morgados [entail; majorat], brasileiros ['Brazilians'], ${ }^{\mathrm{xx}}$ rich merchants and farmers in the neighbourhood were also in the picture, 'some less fortunate and even poor'. It follows from this that, whether we are looking at the 'filhos-de-algo' (fidalgos) [noblemen], that is to say, the compulsory spenders, or the sectors with the least of resources, once the means of subsistence had been exhausted, according to E. Cruzeiro [25], they began to help one another, 'In many cases, in shifts, exploiting, as far as possible, their comrades and all those who offered themselves for this' (p. 812).

Such environments, although in many cases exposing a certain lack of money, did not, however, prevent some lavish living or at least excesses, with many students giving themselves the airs of economic power they did not possess. Having lots of money and 'spending it quickly' seemed to be the rule in certain circles. This also illustrates the symbolism of the informal leisure environments, where the assertion of status required a particular ostentatious posture as the flipside to cultivating charm and popularity. Buying everyone an ice-cream, a chocolate or a glass of wine is something that always goes down well with whoever happens to be around. These mundane and somewhat lavish lifestyles have always been incubators of excess. They are, therefore, pockets of sociability contained in zones that we might say that are on the sidelines of the institutions - or, if we prefer, as being at the borderline of social 'normality' and 'marginality', and sometimes plunging into it. These are precisely the circumstances in which, as various historical records testify, alternative and dissident movements and ways of thinking tend to flourish.

It can be said that it was in these settings or in similar ones that began to develop and spread in nineteenth-century Europe that the early intellectual bohemian ${ }^{\mathrm{xxi}}$ movements began to grow. Although with very distinct characteristics, and in the context of a country still markedly rural and poor, Coimbra favoured - albeit as more of a semblance - the emergence of such environments, at least among the elite of university students. The upper echelons of the student segments could display their privileged standing in a particular way as stated by E. Cruzeiro [25]: 'an excess of underlings, one and sometimes three servants; if he is a nobleman he has his cook, a servant and a page, or at least a black person' (p. 813). But when the money began to run out, imagination came to the rescue to meet needs, including resorting to the so-called prego [spout], a slang term for a pawnshop. Organizing and playing raffles was another practice. All kinds of personal items, with or without value, were raffled such as watches, rings, pistols, spurs, garments, etc. This led to a custom of transactions that were echoed in the Palito Métrico, mentioned earlier.

There was a great variety of remarkable figures in the student circles. At different times, but especially from the end of the nineteenth century and in the first half of the twentieth, they were taking shape in the informal atmospheres ${ }^{x i i}$, even though they helped to increase the number of years spent at university, and became important factors in educational enrichment. Like the new urban customs that arose under the influence of the cultural movements that followed the French Revolution, transgressive and bohemian movements crossed Europe. They were affirmed as part of an enriching heritage of centres of learning and student counter-cultures, prompting the germination of socio-cultural movements of great impact, of which, moreover, Coimbra was the stage, particularly in the nineteenth and the first decades of the twentieth century.

With so many centuries of history, the UC was, like other European universities, a fundamental institution in the formation of the country's political, cultural and intellectual elites. In addition to knowledge and the formal importance of academic qualifications, university attendance was in itself a guarantor of distinguishing prerogatives and high status. The weight of history together with the university's close interweaving in the life of the city, which is projected as a university city, have helped to build a particular identity, strongly indebted to the student presence and academic knowledge. These historical attributes have made Lusa-Atenas one of the cities most glorified and sung about by poets and writers down the ages. Camões, Garrett, Antero, Eça and, more recently, Manuel Alegre, are just some of the famous names who have left their mark on it. And in addition to literature and poetry we have the Coimbra fado and guitarra [Portuguese guitar] ${ }^{\mathrm{xxiii}}$. Although not the main focus of this text, it is important to highlight their role in the development of student culture in general and their contribution to the consolidation of the resistance 'counter-culture' in particular, especially in the last years of the 'New State' [the Estado Novo regime].

\subsection{Contested Masculinity and Resistance: the 1960s}

An inescapable aspect of any reflection on academic traditions and symbolic violence is the masculine stamp that has been ingrained in the system of higher education since its inception. The first woman in Portugal to attend the university was Domitila de Carvalho ${ }^{\text {xxiv }}$. She entered UC in 1891 and completed the courses of mathematics, philosophy and medicine in that decade. She was awarded her PhD in 1904.

We should not forget that there prevailed a mentality which besides being based on traditionalist values, cultivated a multitude of conservative references and forms of subordination of women. Although it remained the pretext of a romantic discourse, the female condition nonetheless still played a secondary role, sometimes regarded as a mere sexual object, even in the context of student culture (whose 
most common stereotype was the figure of the sopeira

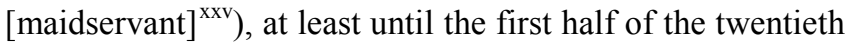
century. As we know, the Salazar regime sought to perpetuate this conservative and macho morality, largely supported by the doctrine of the Catholic Church ${ }^{\text {xxvi }}$. However, the University was becoming feminized and it was already receiving a significant number of women in the 1950s. Hence, despite the authoritarian regime and powerful cultural obstacles, the spark of sexual liberation of the 1960s also glimmered in our country, including in the student world. At that time, there was an open debate about the conditions of 'socialising' between the two sexes, where the discussion about the 'sexual roles' had been ongoing in Coimbra for some time.

The high point of this first debate on the issue of women's liberation was the publication of Carta a uma Jovem Portuguesa [Letter to a Portuguese Girl]. Signed by an Anonymous ' $A$ ' [31], it would later be claimed by Artur Marinha de Campos:

\section{'Young Portuguese woman! I give you my hand and my body. I feel your fingers, your arm. I feel a young body next to mine. But I am not a mould; I am a young man different from you. A boy for whom love is the sexual achievement, the only difference in the relations between man and woman, which must take place on the same plane as the relations of man to man. We have the same freedom. It was a similar impulse of two free beings that brought us together.'}

The author challenges the abstract figure of a 'young Portuguese woman', extolling in a poetic tone her uneasiness at the social situation of young women, characterized by a conservative 'determinism' that obliged them to live on 'the other side of that wall: the restless world of shadow and mental repression,' mentioning what oppresses and subjugates 'the sexual consummation of love'. The impact of the Letter exceeded the confined limits of the university and caused a wave of indignation on the part of the strata more in line with the regime. According the historian Miguel Cardina [17], they saw the text as 'a direct attack on the Christian religion and the Morality that is within the foundations of our society' (p. 130).

The direct causes of the student movement were, in addition to some contagion from the winds of international youth rebellion that had penetrated the country, despite everything, mainly related to the asphyxia in which one lived in political terms. There was a very conservative university, lacking political, civil and associative freedom; there was a centralist and strongly repressive state and, above all, there was a colonial war for which successive contingents of young people were mobilized (many of them were killed or wounded in combat in Angola, Guiné-Bissau and Mozambique).

This close link between academic tradition and political action could be expressed, for example, in the inclusion of pictures or messages of denunciation of the regime in the rituals along the sixties. This actually happened in the Latada parade of 1961/62, when a car pulled by a black student displayed the slogan of the regime, Angola é nossa! [Angola is ours!]. And there was a very sarcastic poster bearing these words: O Tó [Salazar] tem um cancro. Coitado do cancro! [Tó (Salazar) has cancer. Poor cancer!] In some phases since this period, as stated by Dias and Sá [32]:

'academic initiation rituals have played an important role as a political instrument in the opposition to Salazar's dictatorship and the colonial war, since they were used to disguise academic traditions as anti-regime interventions' (p. 22).

It should be noted, however, that in Coimbra the challenge to the conflict in the colonies occurred only from the end of the sixties onwards. This was also the period (1961-1964) that saw the new musical sounds and poetic output that were to be associated with the new protest song 'genre' spreading in the city. New references and new cultural values were disseminated by music, lyrical ballads and poetry. Names like José Afonso and Adriano Correia de Oliveira rose to prominence, and with them the new and irreverent musical-cultural movement of protest against the regime really took off. ${ }^{\text {xxvii }}$

It can therefore be said that the combination of the student movement and the traditions helped to camouflage organized resistance and keep it underground. Also M. Cardina [18] alludes to this when he says:

'the use and the symbology of the rituals enabled the challenge to become part of the flow of the traditional Coimbra experiences. This not only lent them legitimacy but evoked a certain complacency in the national ruling elite, for whom Coimbra was still both the place where a certain corporate, bohemian and romantic spirit prevailed and the location of a university institution that produced the brains of the regime' (p. 117).

In addition, Salazar retired from office in 1968, to be succeeded by Marcello Caetano (former rector of the Instituto Superior Técnico de Lisboa) with the promise that the regime would open up. Hence the aura of a period that remained in history as the 'Marcelista Spring' (read as beautiful, promising, but of short duration).

The event of the so-called 'Academic Crisis of $1969^{\text {'xxviii }}$ unleashed a period of academic mourning, ${ }^{\text {xxix }}$ which resulted in the suspension of student festivals and of the initiation rituals perpetrated on freshmen. From then until the late 1970s, the traditional garb was only worn on special occasions, ${ }^{\mathrm{xx}}$ in particular as a form of protest at the regime. However, by then the use of the costume had come to be seen as somewhat incompatible with the protest action of this student generation. It was in this context that it was decided to suspend the festivals and the customary processions, as well as the usual freshman rituals, but the principle of wearing the cape from the shoulders, with the clasp of the 
cassock tight around the neck was established, with the ribbons, pins and regalia hidden. Meanwhile, contrary to the view prevailing among students today, the controversial issues related to tradition did not go away, and their political significance before and after 1969, with multiple reconfigurations and forms of collective action, continued. These practices arose both in the socio-political arena and in the narrower cultural and ritualistic dimension, where the praxe rituals were still the focus of controversy (although more sporadic) that fuelled dissension between rival groups.

\subsection{Recent Trends: Naturalizing Despotic Power}

The psychological element is undoubtedly the epicentre of all this perverse logic: expectations are created that, in general, exceed the vulnerability of the victim, leaving him unsure of what can happen to him, but at the same time trying to measure how much he can endure. It is in this game that you try to test the mental strength of the other. This is where the symbolic power creeps in, between the ability to 'swallow' the most repugnant situations and the free will of those who are invested with power and who often convey this message: 'I'm not going to harm you, but I would if I wanted to'. The game can therefore evolve in the opposite direction, that is, from the situation of abuse to the gesture of affection and solidarity. Many of the students I interviewed mentioned this. When you move from the usual rites-of-passage context to the party environment, relationships change substantially. It is important to emphasize that freshmen can also sometimes gain the upper hand over the 'doctors'. One of the times this is particularly evident is in the contest between 'godfathers/godmothers' for 'godsons/god-daughters', since it turns into a status symbol for the older students to see who gets the most godchildren. In any case, one of the points that must be stressed and understood regarding the attitude and obedience of freshmen relates to their difficulty in saying 'No!'

It is worth noting an instance of direct observation that took place at the end of 2014 in the Botanical Garden, a park in Coimbra that is relatively quiet, especially in winter when the weather is somewhat harsh, as was the case. By watching the group's behaviour in a collective ecstasy, the reading of the situation could only become even more critical insofar as it concerned disciplinary practices, cloaked in a strong symbolic power, but at the same time indicative of consent and naturalization of submission. So let us look at the picture I have drawn in a newspaper article [33] about the occurrence:

By chance, when I was walking in the Botanical Garden in Coimbra a few days ago, on a rainy day, I realized that there was a noisy party by the artificial lake in the garden. I went closer and looked, saw and took a photo: about a hundred young people, most of them wearing the academic garb, were engaged in an initiation ritual, around the edge of the lake, where a number of freshmen (men on one side and women on the other) were bathing, shrunken beneath the water and clinging to the edge, when it was pouring with rain, some were shivering with cold, while the 'doctors', wooden spoons at the ready, poured spoons of water over their heads. Some had already got out, still shivering and wrapped in capes, but when I asked them they assured me that they were there of their own volition... Some would say that this is not a 'real' initiation ritual, others, like them, would say that it is all happening freely and voluntarily. You do not have to be a sociologist to know that 'experience' is not a crucial requisite for rigorous knowledge, sometimes quite the opposite (...)'.

It is true that the freshmen got out of the lake shivering with cold and wrapped in the cloaks of their 'godfathers'. But they all said that everything that happened there was a matter of free choice and done in the name of the integration that the rituals provide. Assertions, however, that were stammered out while hands were trembling with cold, and all under the watchful eye of the older students. It is therefore important to interpret the subtext in its specific context, because only then can we deconstruct the 'myth of enthusiastic acceptance' by freshmen. That is, following Bebiano [34]:

'faced with a scenario of inevitability [they] know quite well that if they try to resist, they will be ostracized, «de-integrated» by many of their colleagues, when not coerced psychologically or even physically'.

Note that the phenomenon is widespread and occurs in all universities and colleges in the country. In order to understand its acceptance among the students, we only need to recall the views most often expressed in an auditorium of the University of Lisbon in 2012 during a debate where a documentary film (by Bruno Cabral) entitled Praxis was shown. ${ }^{\text {xxi }}$ Some of the comments by the students stressed ideas such as: initiation rituals are humiliating practices whose purpose is to create a common enemy for freshmen, so that they can interconnect (older male student); what I felt when I was a fresher, when they ordered me to look at the floor and I exchanged a glance [underneath] with my colleague beside me, looking at the floor, but that created a connection with the person beside me (female student in traditional attire); these rites-of-passage do not teach us to read or to write, but they do teach us that we all have the right to be humiliated; I'm a freshman and I'll tell you just one thing: I love the rituals! (female student, the comment that received loudest applause).

Take the case of Alexandra, a former student at the São Vicente School of Nursing in Lisbon. In the first few weeks after arriving from the Algarve, she had enjoyed herself with the other colleagues who entered the nursing course, although the 'godfathers' had painted her face, called her 'beast' and forced her to sing the song of the 'dairy cow' in the middle of Campo Grande in Lisbon. Her account of the time she was awaiting 'trial' with other colleagues is striking. Standing next to the door of a closed room, she could hear shouts coming from inside which seemed like cries of distress. She did not know what was going on. She was 'a bit nervous', she says, but never thought of opposing what they 
wanted to do. Finally it was her turn. They ordered her to take her shoes off and asked her to come in, then she found a rug stuck with drawing-pins, sharp side up, that crossed the entire room. In the middle was a narrow strip without pins, where she would have to tread. But then they required her to do it barefoot and hopping (only one foot on the ground), and after that she was blindfolded. She had no idea that the rug was to be quietly removed once she was wearing the blindfold. Meanwhile, she could still hear agonized cries, which were being faked, but she did not know that. She thought that if the others had made it through the drawing-pins then she would, too. 'I really thought that I was hoping to get away from the drawing-pins... It was horrible.' However, she later gave herself up to the cause. (Alexandra Mendonça, 33, former student at the São Vicente de Paulo School of Nursing, Lisbon)

It is not unusual for attitudes to change when making the move from freshman to 'doctor' (that is, from 1st to 2nd year student). As freshmen they remain generally watchful or even fearful, at least in the arrival period. A lot of them consider the jokes to be pathetic and senseless, and see the whole thing as rather ridiculous. Then they change. They feel surprised by this: as one former student said, 'when I'm wearing the attire, I feel like someone else'. Switching 'positions' means acting in accordance with what is expected of the new 'rank'. In a word, the rationale of domination does not change just because there is a change of protagonists or the status is changed within the hierarchy. This means that social power is far more perverse and pervasive than it seems. These students may never read Michel Foucault or Pierre Bourdieu, but they certainly quickly learn to serve as vehicles of the capillarity of symbolic power and reproduce it on a grand scale.

\section{Conclusions}

Looking at this process in the light of the profound social changes in Portuguese society since the democratic opening up in 1974, its enormous reach in the university field and its various spaces of sociability is undeniable. The rites-of-passage are therefore inseparable from more general social trends and, above all, from the profound change that the Portuguese university system itself has undergone in recent decades. Hence the inevitable change, if not the actual 'reinvention' of these traditions. Increasingly larger segments of students from the working class began to enter higher education (public and private), providing it with a rationale of 'massification'. At the same time, the general process of modernization and urbanization of society has significantly altered the social status and standards of living of the students' families of origin. The new urban risks and the disappearance of the old street, village or neighbourhood environments have brought about scattering, isolation and loneliness among the current generations of adolescents, who have little inclination for associative involvement and find secondary sociability problematic.

Of course all this change occurs under a process of rebuilding identities or, I should say, under the subjective effect of searching for furtive forms of identification by the academic youth. The illusion of accessing a superior status is a prospect that favours acceptance and the young men and women (especially those coming from the more rural areas) arriving in the University City learn fast that they need to be accepted by the older colleagues. In these environments, excessive alcohol consumption ${ }^{\text {xxxii }}$ [the so called 'binge drinking'] became a serious problem in Coimbra. These orientations shatter the old critical-sense atmospheres, replacing the former repertoires of student movements with allegiance to market logic and its lucrative goals. Thus, the entry into higher education is a first plunge into collective life and this happens at a time when many young people feel, for the first time, free of family control, in a context where group cooperation, sharing between colleagues, etc., operate as strong appeals to student youth. It follows that the explanation for such an unconditional surrender to these practices must relate to the indomitable desire to become part of the group, the attitude of amazement and the feeling of solidarity among equals, in a dizzying phase of rise in status. The widespread notion of a generalized individualism within the younger generation does not square with reality. The students experience considerable insecurity and when they enter the University their individual vulnerability becomes more exposed.

This is why they recognize and project themselves within the group. The group of classmates becomes their main anchoring point. The gestures of acceptance of the initiation rituals and the 'respect' that the freshers are called upon to show to their older partners mean that the occasions of 'submission' are transitory experiences. However, group dynamics motivate them to build their own sense of emancipation, especially from the point when the 'fresher' is promoted to 'doctor'. The volatility of the status enjoyed follows a psychosocial rationale of projective transference, but in this process the culture of subjection to power is boosted and naturalized. So, as discussed initially, tradition is more a discourse turned into an instrument of legitimisation of power relations than an appeal to historical heritage. The community sense of belonging has been strong while UC was an exclusive site for the upper strata, but nowadays, the Praxe rituals have become a performance that works as a catharsis to help acceptance and consent vis-à-vis the established hierarchy. This power rationale system is based upon the pure principle of 'strength'. A strength that allows the rapid passage from submission to domination as the freshmen move from the first to the second school year.

It's true that the old Republics are still places where an alternative and critical spirit survives. But they are a very small minority (around 120 students, 25 houses) and have no impact on the mass of students (around 21000 ). Nowadays we are far from the periods of struggle against colonial wars and the rituals have become detached from any cultural 
irreverence or any sense of political critique. Tradition became a kind of 'empty narrative' that is now symbolically strong in the eyes of the new generations, but most of the students not only ignore the struggles of the past and their legacy, they also plunge acritically into the consumerist lake (full of beer and other alcoholic drinks).

The cult of initiation rituals represents an endurance test and, at the same time, a kind of idolization of 'authority'. It is a cult that presents itself as the denial of democracy (it offends individual rights) and meritocracy (the most senior is whoever has failed most). Some young students go so far as to claim 'the right to be humiliated', a formulation that is clearly paradoxical but nonetheless it does show how this ritual represents a dangerous game that glorifies subjection to power. Any power. The right of the strongest to issue orders and the duty of the weakest to obey. It is only an embryonic attitude, but it could well become an embryonic authoritarianism that flourishes.

\section{REFERENCES}

[1] Gennep AV. Les Rites de Passage étude systematique. Paris: Uitg. E. Nourry; 1981[1909]

[2] Burawoy M. Manufactiru«ing Consent. Chicago: The University of Chicago Press, 1982.

[3] Bourdieu P. Hommo Academicus. Mngualde: Editora Pedago, 2016[1984]

[4] Foucault M. Vigiar e Punir. Petrópolis: Editorial Vozes; 1977.

[5] Elias N. O Processo Civilizacional. Lisboa: Dom Quixote (vols. I e II); 1989.

[6] Lipovetsky G. Metamorfoses da Cultura Liberal. Porto Alegre: Editora Meridional; 2004.

[7] Estanque E, Fonseca D. Olas de Indignación y su Lógica Política: movimientos sociales y nuevas expresiones de radicalismo de clase media. Revista de la Asociación de Sociología de la Educación (RASE)/ Universidade de Valência, 2014, vol 7 (3): 587-607.

[8] Estanque E, Bebiano R. Do Activismo à Indiferença. Movimentos estudantis em Coimbra. Lisboa: Instituto de Ciências Sociais; 2007.

[9] Marcuse H. O Homem Unidimensional. Sobre a ideologia da sociedade industrial avançada. Rio de Janeiro: Zahar Editores; 1982 [1964]

[10] Debord G, Society of the Spectacle. Detroit: Black \& Red; 1983.

[11] Baudrillard J. Simulacros e Simulação. Lisbon: Relógio D’Água; 1991.

[12] Gil F. Portugal Hoje: o medo de existir. Lisbon: Relógio D’Água; 2007.
[13] Santos BS. Portugal. Ensaio Contra a Autoflagelação. Coimbra: Almedina; 2012.

[14] Estanque E. Classe Média. Ascensão e Declínio. Lisbon: Fundação Francisco Manuel dos Santos; 2012.

[15] Cardina M. Memórias incómodas e rasura do tempo: movimentos estudantis e praxe académica no declínio do Estado-Novo. Revista Crítica de Ciências Sociais, 2008, nº 81: 111-131.

[16] Cruzeiro C. Coimbra, 1969. A crise académica, o debate das ideias e a prática, ontem e hoje. Porto: Edições Afrontamento; 1989.

[17] Namorado R. Para uma Universidade Nova: crónica da crise de 1969 em Coimbra. Revista Crítica de Ciências Sociais, 1989, vol. 27/28: 63-124

[18] Cardina M. A tradição da contestação: Resistência estudantil em Coimbra no Marcelismo. Coimbra: Angelus Novus; 2008.

[19] Beck U. Sociedade de Risco Mundial. Lisboa: Edições 70; 2007.

[20] Castells M. Networks of Outrage and Hope: Social Movements in the Internet Age. Cambridge: Polity Press; 2012.

[21] Estanque E. Praxe e Tradições Académicas. Lisbon: Fundação Francisco Manuel dos Santos; 2016.

[22] Santos BSS. Os conflitos urbanos no Recife: o caso do 'Skylab'. Revista Crítica de Ciências Sociais, 11: 9-60; 1983.

[23] Burawoy M. Ethnography Unbounded. Power and resistance in the modern metropolis. Berkeley: University of California Press; 1991.

[24] Fine GA. On the macrofoundations of microsociology. The Sociological Quarterly, 32(2): 161-177, 1991.

[25] Cruzeiro ME (1979). Costumes estudantis de Coimbra no século XIX: tradição e conservação institucional. Análise Social. 1979, Volume XV (60): 795-838.

[26] Bastos HT. A vida do estudante de Coimbra, antiga e moderna: duas conferências na Associação Cristã de Estudantes, nos dias 29 e 30 de abril de 1920. Coimbra: Imprensa da Universidade; 1920.

[27] Torgal LR, Dias P. A Universidade de Coimbra (2 ${ }^{\mathrm{a}}$ Edição). Coimbra: Imprensa da Universidade de Coimbra; 2015.

[28] Nunes AMM. (2004). As Praxes Académicas. Sentido actual e perspectivas. Cadernos do Noroeste, Instituto de Ciências Sociais da Universidade do Minho, 2004, Vol. 22 (1-2): 133-149.

[29] Lamy AS. A Academia de Coimbra, 1537-1990, História, Praxe, Boémia e Estudo, Partidas e Piadas, Organismos Académicos. Lisboa: Rei dos Livros (2nd edition); 1990.

[30] Frias A. Praxe académica e culturas universitárias em Coimbra. Lógicas das tradições e dinâmicas identitárias. Revista Crítica de Ciências Sociais, 2003, 66: 81-116.

[31] Anonimous. Carta a uma jovem portuguesa. Jornal Via Latina - órgão da Associação Académica de Coimbra, 19/04/1961, $\mathrm{n}^{\mathrm{o}} 130$.

[32] Dias D, Sá MJ. Rituais de transição no ensino superior português: a praxe enquanto processo de recomposição identitária. Revista Galeco-Portuguesa de Psicoloxía de Educación, 2013, vol. 21(1): 21-34. 
[33] Estanque E. A praxe e o novo tribalismo [Initiation rituals and the new tribalism]. Público newspaper, 22/10/2014.

[34] Bebiano R. Cinco mitos em torno das praxes. Esquerda.Net. Available in

http://www.esquerda.net/dossier/cinco-mitos-em-torno-das-pr axes/31287 (Accessed 12th September 2015).

[35] Murger H. Scènes de la Vie de Boheme. London: Vizetelly \& $\mathrm{C}^{\mathrm{o}} ; 1851$.

${ }^{\mathrm{i}}$ Note that the clauses of the Código da Praxe, although they seem to be extremely detailed, do, in a great many instances, allow opposing readings. In addition, it paves the way for a lot of exceptions which, in practice, subvert in some paragraphs what has been established in others.

The Portuguese historian Paulo Archer de Carvalho is quoted in this passage, reproduced in a report of the Portuguese Parliament As Praxes Académicas em Portugal [Academic initiation Rituals in Portugal]. Report of the Parliamentary Committee for Education and Science. Lisbon, 2008.

iii This was a survey jointly organized by 'Universia' and the employment community 'Trabalhando.com'. This group includes the most important institutions of higher education in Latin America (1,345 universities), which encompass 18.3 million students and lecturers, corresponding to about $79 \%$ of the Ibero-American university collective body. The sample consisted of 23 countries, including most of the South American continent plus the USA, Portugal, Andorra and Spain. See the item published in the Diário Económico, 14 December 2015.

Note that the author has been working on these subjects along the last 20 years, including using other research methods, like a large survey on the collective project with R. Bebiano; see note [6]

Inês de Castro (1325-1355) is best known as lover and posthumously-recognized wife of King Peter I of Portugal. She was Spanish descend and well connected to the Castilian royal family. The dramatic circumstances of her relationship with Peter I, which was forbidden by his father King Afonso IV, her murder at the orders of Afonso, Peter's bloody revenge on her killers, and the legend of the coronation of her exhumed corpse by Peter, have made Inês de Castro a frequent subject of art, music, and drama through the ages.

vi This survey sample included the most important institutions of higher education in Latin America (1,345 universities), which bring together 18.3 million students and professors, corresponding to about $79 \%$ of the Ibero-American university collective. Among the 23 countries included in the sample are the majority of the South American continent, plus the USA, Portugal, Andorra and Spain. See piece published in Diário Económico, December 14, 2015.

vii It is important to underline that the initiation rituals are just one part of a larger set of traditions, including the cyclic festivals, parades and other costumes such as: Latada (a parade related to the initiation school year) Queima das Fitas (a week festival including a parade with decorated vehicles of each faculty and courses) Ceremonial Ball, Bullfight, etc. The term "Praxe" can be referred only to the initiation rituals toward the freshmen but sometimes is also used in a broader sense.

viii viii The creation of the Portuguese General Study by D. Dinis signing the document Scientiae thesaurus mirabilis took place on 1 March 1290. It was confirmed by the bull De statu regni Portugaliae, issued by Pope Nicholas IV (9 August), with the Faculties of Arts, Canon Law (Canons), Civil Law (Laws) and Medicine, beginning to function in Lisbon. A number of changes took place in the University in the ensuing centuries. The General Study moved to Coimbra in 1308, returned to Lisbon in 1338 and went back to Coimbra in 1354. It moved to Lisbon again in 1377 and before being finally, definitively installed in Coimbra in 1537 .

ix There are records stating that that the same group of offenders attempted to kidnap the daughter of the Rector, Dr Sanches de Baena.

${ }^{x}$ This observations were referred by António Nunes Ribeiro Sanches, an important scientist and intellectual of the eighteenth century (medical doctor, philosopher, pedagogue, historian), of Jewish origin (he became a New Christian). He studied philosophy and law in Coimbra, but in 1720 he left this university with criticisms of the type of teaching given and the bohemian lifestyle of the students. A victim of persecution, he was forced into exile in 1726 and travelled throughout Europe, passing through severa universities such as Salamanca, Paris and St Petersburg. He received honours from Catherine II of Russia and was appointed State Councillor there. He was a member of the Academy of Sciences of St Petersburg, the Academy of Sciences of Paris and the Royal Society of London. Among the various works he published is the Cartas Sobre a Educação da Mocidade [Letters on the education of youth] (1760). On his return from Russia he became adviser to the Marquis of Pombal and helped to support the reform
[36] Bakhtin M. Cultura Popular na Idade Média: o contexto de François Rabelais. SP: Hucitec; 2010.

[37] Estanque E. Juventude, boémia e movimentos sociais: culturas e lutas estudantis na universidade de Coimbra. Politica \& Sociedade, 2010: 257-290.

[38] Samara MA. Operárias e Burguesas. As Mulheres no Tempo da República. Lisboa : Esfera dos Livros; 2007.

of the university. The passage cited here by E. Cruzeiro is taken from Método para Aprender e Estudar a Medicina [Method to learn and study medicine], 1763 (outcome of his collaboration with the Portuguese government), documents currently included in the database of the University of Beira Interior,

http://www.estudosjudaicos.ubi.pt/rsanches_obras/metodo_aprender_estud ar med.pdf, accessed on 4/02/2017.

xi The punishment called 'going for the nails' consisted of caning (with a ruler or wooden spoon, sometimes until blood was drawn) was traditionally inflicted on the novices (freshmen) as part of the initiation rituals such as trials or punishments carried out by the Trupes. Other punishments can be classed as 'insult', 'mockery', 'bullfight', 'teasing', etc., and they took different forms but always ended in disqualification/humiliation - even if dressed up with humour and sarcasm - of the novices by the older students. xii As noted, the prerogatives of the university bodies (students, faculty and staff) were in force from the founding of the University and the Prison itself had been demanded long before its official creation. In the first period, from 1593 , the Academic Prison's dungeons were underneath the Sala dos Capelos (the flagship UC space where the $\mathrm{PhD}$ examinations still take place) and later, after the 1772 reform of the Marquis of Pombal it moved to premises underneath the Joanine Library. The main focus of the Liberal Revolution of 1820 was the city of Porto, and it had major repercussions in the country and also in Brazil. It led to the return of the Court to Portugal and the subsequent independence of Brazil. In Coimbra, the Academic Forum was abolished along with the special jurisdiction for teachers, students and their families, which also put the end to the UC prison.

xiii The academic garb has evolved over time and is a hallmark often seen today around the university of Coimbra, with black being its most distinctive feature. It is particularly noticeable in periods when the rituals are most in evidence, which is at the start of the academic year/September-October (period of Freshers' Welcome and the Latada parade) and the month of May (Queima das Fitas parade). It should be noted that in Coimbra the initiation rituals continue throughout this period, in other words they span pretty much the whole academic year. The garb includes the cape and cassock, trousers for the men and a skirt for the women. Depending on the circumstances, the so-called 'insignias' ['regalia'] may or may not be worn. They comprise ribbons with different colours according to the faculty, a black leather portfolio, a turnip, a cane and top-hat; these latter are used by the final year students during the Queima das Fitas parade.

xiv This is the name of one of the bells of the university tower, see Note 13, below.

xv The Council of Veterans is the highest authority in the hierarchy of the academic initiation rituals. The members of the Council appoint its head, who, in the case of Coimbra, is called the Dux Veteranorum. The membership includes (or can include) those students whose number of registrations exceeds the number of academic years of their course.

${ }^{x v i}$ In Coimbra there are 17 categories in the praxe hierarchy ranging from the lowest, the bicho [bug], which is the secondary school student, to the Dux, the top man). A pastrano is a first-year student who registered between the period of Queima das Fitas and the start of the next academic year.

xvii The University Tower consists of a set of bells and clocks which, according to tradition, regulate the academic rhythm (it is known as ' $c a b r a$ ' ['slut'], but this is the name of just one of the bells; the others are known in academic slang as 'cabrão' ['bastard'] and 'balão' ['balloon']). There are two main peals: the matutino [morning] (between 7.30 and 8.00), and the vespertino [evening] (between 1800 and 18.30), which, respectively, establish the start and end of teaching activities. According to the Código da Praxe, this is only allowed between the first morning peal and the last evening peal. However, several exceptional situations are envisaged. There are peals throughout the day that mark the start of classes. The period from $11.30-24.00$ is known as the 'freshman time', when freshers cannot be subjected to initiation rituals. Outside this period, after the last midnight chime, any freshman caught on the street by a trupe can be questioned, tried and punished.

xviii The Palito Métrico ['Metric Stick'] first appeared in 1746 and its last edition was published in 1942. It was a collection of publications, with poems, letters and recommendations written in broken Latin, signed at first 
by António Duarte Ferrão, a pseudonym attributed to a secular priest, Father João da Silva Rebello (1710-1790), Doctor of Theology and Canon Law from the UC.

xix The term has a pejorative connotation; it is linked to sub-standard business, junk items, cheap clothing, etc. To dress like a commoner was to dress 'in plain clothes', synonymous with shabby garments or with 'an insignificant person'. In any case, the word was widely used in Coimbra to distinguish students from 'non-students'.

${ }^{x x}$ At the time, this designation was synonymous with ex-emigrants who returned from Brazil (generally successful and supposedly very wealthy).

xxi The first bohemian movements were started by famous figures such as Charles Baudelaire, the exponent of symbolism and the flâneur or dandy style, whose art, poetry and erratic, marginal lifestyle were designed to shock and offend the prevailing morality. In many settings throughout the Middle Ages, but especially with the emergence of the Modern Era and the impact of the new philosophical currents, especially the Enlightenment, poets, musicians, artists and intellectuals (many of them breaking from their aristocratic, noble or bourgeois origins) headed into the submerged an sometimes unbridled dimension of popular culture as an act of rebellion against conventions and the prevailing morality. As I noted in a previous paper, the writer and playwright Henri Murger [35] was the first to promote and reflect on the bohemian way of life in his play Bohèmes $d u$ Ouartier Latin (1849), subsequently published as a book under the title Scènes de la Vie de Boheme (1851). Bohemians first appeared in the era of classical Greece. They were initially associated with the hungry and with vagrants sometimes linked with thieves and vagabonds who wandered around wealthy and hospitable environments, begging and playing the lyre in devotion to Helen and the fall of Troy. The phenomenon has been adapted over time and acquired links to gypsy ethnic groups, a nomadic people who roved aimlessly and who, in the mid-nineteenth century, created the idea that they came from Bohemia, a region in today's Czech Republic. By analogy, groups of artists and intellectuals of the time, whether impoverished or not and including G. Coubert, P. Verlaine, A. Rimbaud, E. Zola and H. Balzac, adopted ways of life with some similar characteristics, especially in the sense of rejection and open criticism of prevailing morality as noted by Bakhtin [36] and Estanque [37]

xxii Locally famous names such as Pad'Zé, Pássaro, Condorcet, Pantaleão, Castelão de Almeida, etc., left their mark on the city as 'bohemian students'. The last two founded the satirical newspaper Ponney in 1929. It published a number of caustic articles on the university and socio-political landscape of the period of the military dictatorship (1926-1933) and afterwards, at the start of the New State [Estado Novo], having achieved the status of 'newspaper with the largest circulation in Coimbra' (cf. O Ponney, Anno II $n^{\circ}$ 43. Coimbra: Tipografia Da Atlantida, 1931).

xxiii Artur Paredes, Carlos Paredes, António Portugal and António Brojo (on the guitarra) and Augusto Hilário, Luiz Goes, José Afonso, Florêncio de Carvalho, Fernando Rolim, among others (in Coimbra fado), are some of the artists who became famous, especially from the 1950s and 1960s. Not long afterwards the new sounds began to be developed and the politicization of this area started, with what is known as 'intervention music' (of which José Afonso was the main exponent).

xxiv According to Samara [38] as a condition of admission she was told by the Rector to always dress modestly in black and wear a discreet hat so that she wouldn't be conspicuous among her male colleagues.

${ }_{\mathrm{xxv}}$ In colloquial language sopeira was the name given to maidservants. And in Coimbra this was at a time when girls were a tiny minority of the students. They were sometimes female figures who worked in domestic service in the student houses (known as Repúblicas - Republics), and were often subjected to sexual harassment by the 'boys' they worked for.

xxvi We may recall the old trio of God, Homeland and Family, the famous design imprinted on the cover of the books of what used to be the $2^{\text {nd }}$ year school books, as a caricature that summed up the ideology of the Salazar regime.

See the very active Blog "A Terceira Noite", in < http://www.aterceiranoite.org/2014/01/26/cinco-mitos-em-torno-das-praxes >. Accessed 23. 04.2017

xxviii The 'Academic Crisis of ' 69 ' was a particularly intense period for the student movement in the UC, as it struggled for freedom of association, for a democratic University and protested against the Estado Novo regime. It included an act of great symbolism and irreverence when, on 17 April of that year the elected official of the Coimbra students union (AAC), Alberto Martins, took the floor at an official ceremony, in the presence of the then President of the Republic (Américo Tomaz), in a power-defying gesture. This triggered a number of initiatives, repressive actions and imprisonment, as well as protest movements, refusal to sit exams and other forms of boycott and street protests. A movement that had a national impact and rocked the regime.

${ }_{\text {xxix }}$ It should be remembered that some Republics still remain today, in a mourning mode, since this has never been lifted by the body that 'decreed' it, the Council of Republics, where, under its statutes, decisions have to be unanimous

xxx One of these symbolic occasions occurred in 1969 at the Portuguese football cup final between Benfica and Académica de Coimbra (Lisbon, National Stadium, 2 June 1969), in the aftermath of the Academic Crisis. The players entered the field with the black cloaks on their shoulders, symbolizing their solidarity with the student struggle.

${ }_{\mathrm{xxxi}}$ This is a very enlightening film in terms of perversion and violence that the initiation rituals have involved in Portugal. It is worth accessing and viewing:

$\mathrm{http} / /$ uniarea.com/praxis-documentario-do-que-nao-deve-ser-a-praxe-ou-re producao-fiel/

xxxii Highly symptomatic of the appeal to consumption and the excesses underlying the praxist culture is, for example, the provision in the Código da Praxe (Article 162 of the Code, updated in January 2016) that one of the situations in which the freshman is 'self-protected' (read, cannot be forced to undergo the rituals) when under the 'protection of the God Bacchus', that is, when he is 'extremely drunk'. 